DOI: $10.14451 / 2.140 .29$

\title{
НАЛОГОВЫЕ ПРАВОВЫЕ ПОЗИЦИИ СУДОВ В СФЕРЕ ЗАКУПОК ДЛЯ ГОСУДАРСТВЕННЫХ И МУНИЦИПАЛЬНЫХ НУЖД
}

\author{
(C) 2020 Паулов Павел Александрович \\ кандидат юридических наук, доцент \\ Самарский государственный экономический университет, Россия, Самара \\ (c) 2020 Мешалкина Анна Дмитриевна \\ студент-магистрант института права \\ Самарский государственный экономический университет, Россия, Самара \\ E-mail: anna-meshalkina6@mail.ru
}

\begin{abstract}
В статье анализируются закупки для государственных и муниципальных нужд во взаимосвязи с налоговым законодательством. Рассмотрена правоприменительная практика судов, сформированная в налоговых правовых позициях, определено значение практического осуществления указанной деятельности.
\end{abstract}

Ключевые слова: государственные и муниципальные закупки, налоговые правовые позиции, Верховный Суд Российской Федерации, Арбитражный Суд, защита прав налогоплательщиков и налоговых органов, налоги.

Закупки для государственных и муниципальных нужд представляются актуальным аспектом деятельности государства, при осуществлении которой особое место отводится соблюдению баланса публичного и частного интереса. Нормативно-правовое регулирование указанного процесса является специфичноопределенным, а его соотнесение с налоговым законодательством представляется актуальным вопросом не только в теории юридической науки, но и при практическом применении норм права. Насущность исследования также обусловлена соотношением баланса интересов в сфере налогообложения, государственных и муниципальных закупок и их отражении в налоговых правовых позициях судов.

Нормативно-правовое регулирование государственных и муниципальных закупок в России представляется сложной сферой отечественного законодательства, что влечет за собой неоднозначное правоприменение указанных норм. Данное положение обуславливается несколькими основаниями, к числу которых относятся комплексный характер возникающих правоотношений, объединяющих в себе административное, финансовое, гражданское право. Налоговое регулирование контрактной системы в сфере государственных и муниципальных закупок остается существенной проблемой, которая зачастую не разрешается в административном порядке, в данном случае участники правоотношений вправе прибегнуть к конституционному праву на защиту своих прав и законных интересов в судебном порядке [1]. Посредством рассмотрения и разрешения споров, возникающих между участниками закупок для государственных и муниципальных нужд и налоговыми органами, формируются налоговые правовые позиции.

Потребность соблюдения баланса публичных и частных интересов обуславливается направленностью исполнителя контракта на извлечение максимально возможной экономической прибыли и обеспечении рационального и эффективного расходования бюджета. Сбалансированность указанных компонентов осуществляется посредством удовлетворения публичных потребностей путем реализации частного интереса, сопряженного с уплатой налогов, сборов и иных обязательных платежей. Налоги выступают в роли императивного регулятора в осуществлении государственного управления, а также являются элементом доходной части бюджета.

Налоговые правовые позиции судов, сформированные при разрешении соответствующих споров в сфере государственных и муниципальных закупок и налогообложения представляются актуальной частью налоговых правовых позиций, полагаем необходимым обратиться к правоприменительной практике для рассмотрения указанного правового феномена. 
Не указание в условиях контракта сведений об уменьшении его суммы на соответствующий размер налога на добавленную стоимость не может расцениваться в качестве нарушения положений Федерального закона «О контрактной системе в сфере закупок товаров, работ, услуг для обеспечения государственных и муниципальных нужд» от 05.04.2013 № 44-Ф3. К данному выводу пришла Судебная коллегия по экономическим спорам Верховного Суда Российской Федерации и изложила его в определении от 30.05.2019 № 305-ЭС19-391 по делу № А40-88142/2018. Отменяя решения антимонопольного органа и судов нижестоящих инстанции, суд указал, что данные правовые основания не могут быть применены к спорным правоотношениям ч. 13 ст. 34 Федерального закона «О контрактной системе в сфере закупок товаров, работ, услуг для обеспечения государственных и муниципальных нужд» от 05.04.2013 № 44-ФЗ (далее по тексту - Закона «О контрактной системе»), поскольку данные положения не направлены на регламентацию изменения цены контрактов в зависимости от применения определенной системы налогообложения. Данная правовая норма направлена на регулирование порядка проведения расчетов при условии наличия особенностей по исполнению налоговых обязательств. Также суд указал на необходимость применения норм права, действующих на момент заключения соответствующего контракта, которые не обязывали контрагента сносить в условия сведения об уменьшении подлежащей уплате суммы на размер налоговых платежей [2]. Изложенная налоговая правовая позиция в сфере государственных и муниципальных закупок указывает на необходимость буквального толкования норм права, недопустимость необоснованного увеличения обязанностей субъектов правоотношений, в том числе посредством обязания их включить в условия соответствующего контракта сведений об уменьшении суммы контракта на размер налога на добавленную стоимость. Указание в проекте договора цены, в размер которой том числе включен налог на добавленную стоимость, не выступает в качестве нарушения действующего законодательства, поскольку не является нарушением прав участников закупки. В соответствии со ст. 173 Налогового кодекса РФ и правовой позицией, изложенной в постановлении Конституционного Суда РФ от 03.06.2014 г. № $17-П$ «По делу о проверке конституционности положений п. 6 и 7 ст. 168 и п. 5 ст. 173 Налогового кодекса РФ в связи с жалобой ООО «Торговый дом «Камснаб» [3], данная обязанность возникает у контрагента только в случае выставления счета-фактуры с указанием суммы исчисленного налога, по инициативе самого налогоплательщика.

Необходимо отметить, что защита прав субъектов правоотношений, возникающих в сфере осуществления государственных и (или) муниципальных закупок может быть осуществлена не только посредствам отстаивания в судебном порядке, но и административном. Жалобы на действия заказчика могут быть направлены в Федеральную антимонопольную службу, указанным правом воспользовался ООО «ПромГражданЭнергоПроф», полагающий, что действия СПБ ГКУ «Фонд капитального строительства и реконструкции» являются незаконными. По результатам рассмотрения указанного заявления были выявлены нарушения п. 2 ч. 6 ст. 83.1 Федерального закона «О контрактной системе в сфере закупок товаров, работ, услуг для обеспечения государственных и муниципальных нужд» от 05.04.2013 № 44-Ф3, заказчик был привлечен к административной ответственности. Не согласившись с указанным решением, СПБ ГКУ «Фонд капитального строительства и реконструкции» обжаловало его в Арбитражный суд г. Москвы [4]. Суд не согласился с доводами заявителя, в т.ч. по причине того, что все участники закупки вне зависимости от применяемой системы налогообложения и наличия обязанности по оплате налога на добавленную стоимость имеют право на участие в закупке, направленной на удовлетворения государственных и (или) муниципальных нужд. Применяемая система налогообложения не имеет определяющего значения при подведении итогов аукциона, в результате которого контракт заключается на условиях предложенной заказчиком цены, соответственно и оплачивается.

Налогоплательщик в определенных случаях может утратить право на применение упрощенной системы налогообложения, в том числе во время осуществления работ по исполнению государственного и (или) муниципального контракта. Ранее определенная стоимость данного контракта, в размер которой не был включен налог на добавленную стоимость, после утраты налогоплательщиком права на применение указанной системы налогообложения должна 
быть увеличена, поскольку в этом случае сумма налога на добавленную стоимость должен быть начислен. Данное положение изложено в налоговой правовой позиции Верховного Суда РФ [5], вошедшей в обзор судебной практики Верховного Суда РФ № 3 (2019). При этом необходимо отметить, что сумма налога должна соответствовать определенной расчетной ставке, применяемой к ранее согласованной твердой стоимости государственного и (или) муниципального контракта.

Необходимо отметить особый вид правовых позиций, сформированный по рассмотрению административных дел, в том числе о признании недействующим письма Федеральной антимонопольной службы. Как ранее было отмечено, указанный орган имеет непосредственное отношение к регулированию деятельности по осуществлению закупок для государственных и муниципальных нужд, но не наделена компетенцией по разъяснению положений Закона «O контрактной системе», а также законодательства России по налогам и сборам. Соответственно письмо Федеральной антимонопольной службы от 18.06.2019 № ИА/50880/19 было издано за пределами представленных полномочий, что нарушает положения налогового законодательства и законодательства в сфере государственных и муниципальных закупок. Верховный Суд, признавая данный разъяснительный акт недействующим, указал отсутствие правовых оснований для заключения контракта государственных и муниципальных закупок с контрагентом, победившим в закупке и применяющим упрощенную систему налогообложения. Данный вывод основывается на комплексном толковании норм налогового законодательства и законодательства в государственных и муниципальных закупок, письмо, в свою очередь, представляется основанием для применения дополнительных условий, что создает общеобязательные правила для неопределенного круга лиц, рассчитанные на неоднократное применение, что является недопустимым.

Юридическое регулирование сферы закупок для государственных и муниципальных нужд представляется актуальным направлением развития законодательства государства, как в точки зрения теории, так и практики применения. Результаты взимания налогов являются не только элементом доходов соответствующих бюджетов, но и императивным регулятором государствен- ного управления. Между субъектами соответствующих правоотношений возникают споры, которые не всегда могут быть урегулированы посредством переговоров, поскольку в данном случае представляется неактуальным применение примирительных процедур в связи с наличием императивного интереса государства. Практическое разрешение спорных ситуаций реализуется посредством использования права на судебную защиту, в результате чего формируются соответствующие правовые позиции.

Налоговые правовые позиции судов в сфере государственных и муниципальных закупок представляются значительным элементом судебной практики, а соответственно и правоприменения действующего законодательства. Вопрос об отнесении решений конкретных судебных инстанций к правовым позициям остается открытым в теории права, в настоящей статье к их числу отнесены решения всех инстанций судебной системы страны. Данное положение обусловлено насущностью рассматриваемой тематики, с точки зрения практического взаимодействия механизма проведения закупок для государственных и муниципальных нужд с нормами налогового законодательства согласно позициям судов.

Рассмотрение налоговых правовых позиций в сфере государственных и муниципальных закупок позволяет определить проблемы, которые возникают в указанной сфере государственного регулирования. Регламентация данного вида закупок представляется сложным алгоритмом действий, в результате исполнения которого могут возникнуть ситуации по нарушению правовых норм, в том числе налоговых. Изложенные примеры налоговых правовых позиций свидетельствуют о наличие ряда спорных ситуаций, разрешение которых было осуществлено в судебном порядке. Не смотря на то, что в налоговых правоотношениях одним из участников является налоговый орган, защищающий интересы государства, являющийся квалифицированным субъектом права, суды признают решения указанного органа незаконными. Сложившаяся ситуация, полагаю, в своей сущности определяется императивным методом регулирования, который складывается как в налоговых правоотношениях, так и в сфере закупок для государственных и муниципальных нужд. Необходимо отметить, что эффективное расходование бюджетных средств не может быть достигнуто 
применением властного регулирования, правовое регулирование указанной сферы может быть признано действенным при создании обоснованного и рассчитанного правового механизма, который обеспечивает баланс интересов участников данных правоотношений. Понятность и прозрачность процедур применяемых в сфере государственных и муниципальных закупок напрямую взаимосвязано с надлежащим осуществлением налогообложения, соответственно эффективное правовое регулирование данных сфер повлечет за собой снижение количества спорных ситуаций, разрешение которых происходит посредством вынесения судебных решений.

\section{Библиографический список}

1. Ревина С.Н., Паулов П.А., Борякин Д. В. Управление закупками и заказами / Электронная информационнообразовательная среда ФГБОУ ВО «Самарский государственный экономический университет» [Электронный ресурс]. URL: https://ms2.sseu.ru/mod/resource/view.php?id=130211 (дата обращения: 01.03.2020).

2. Определение Судебной коллегии по экономическим спорам Верховного Суда РФ от 30.05.2019 № $305-$ ЭС19-391 по делу № А40-88142/2018 // Справочная правовая система «КонсультантПлюс» [Электронный ресурс].-«Версия Проф», 2019.

3. Постановление Конституционного Суда РФ от 03.06.2014 № 17-П «По делу о проверке конституционности положений пунктов 6 и 7 статьи 168 и пункта 5 статьи 173 Налогового кодекса Российской Федерации в связи с жалобой общества с ограниченной ответственностью «Торговый дом «Камснаб» // Справочная правовая система «КонсультантПлюс» [Электронный ресурс]. - «Версия Проф», 2019.

4. Решение Арбитражного суда г. Москвы от 18.12.2019 по делу № А40-182484/2019 // Справочная правовая система «КонсультантПлюс» [Электронный ресурс]. - «Версия Проф», 2019.

5. Определение Судебной коллегии по экономическим спорам Верховного Суда РФ от 16.04.2019 № 302 КГ18-22744 по делу № А58-9294/2017 // Справочная правовая система «КонсультантПлюс» [Электронный ресурс].-«Версия Проф», 2019. 